\title{
Rancang Bangun Sistem Informasi Klinik Umum dan Bersalin Berbasis Customer Relationship Management
}

\author{
Siti Monalisa ${ }^{1}$, Samsul Ma'arif ${ }^{2}$, Fitra Kurnia $^{3}$ \\ ${ }^{1,2}$ Program Studi Sistem Informasi, Universitas Islam Negeri Sultan Syarif Kasim \\ ${ }^{3}$ Program Studi Teknik Infromatika, Universitas Islam Negeri Sultan Syarif Kasim \\ Jl. HR Soebrantas KM.18 Panam Pekanbaru - Riau \\ Email: ${ }^{1}$ siti.monalisa@ uin-suska.ac.id, ${ }^{2}$ samsul.maarif1@ @students.uin-suska.ac.id, ${ }^{3}$ fitra.k@uin- \\ suska.ac.id ${ }^{3}$

\begin{abstract}
Abstrak
Klinik umum dan bersalin Dokter Rini merupakan salah satu klinik yang menyedikan jasa kesehatan. Saat ini, jumlah data pasien klinik yang berkunjung terjadi fluktuatif setiap bulannya dan juga rendahnya pasien yang melakukan konsultasi lanjutan. Hal ini dikarenakan kurang efektifnya pelayanan yang diberikan oleh pihak klinik terhadap pasien dan juga minimnya informasi dalam memberikan pelayanan ke pasien. Oleh karena itu dalam memberikan pelayanan terbaik bagi pasien maka dibangun sistem informasi customer relationship management (CRM) dengan tipe sistem operasional yang dapat membantu mengelola data pasien dengan baik. Selain itu, sistem ini juga digunakan sebagai media promosi dan informasi serta menjalin komunikasi dengan calon pelanggan dan pelanggan tetap dengan menggunakan dua fase CRM yaitu fase akuisisi dan fase retensi. Hasil dari penelitian ini adalah sebuah sistem informasi klinik berbasis CRM dengan fitur reminder system.
\end{abstract}

Kata kunci: Klinik, CRM, Akuisisi, Retensi, Reminder System

\begin{abstract}
Rini's general and maternity clinic is one of the clinics that provides health services. At present, there are fluctuating numbers of clinical patients visiting each month and also the low number of patients who carry out further consultations. This is due to the lack of effectiveness of the services provided by the clinic to patients and also the lack of information in providing services to patients. Therefore, in providing the best service for patients, a customer relationship management (CRM) information system is built with an operational system type that can help manage patient data properly. In addition, this system is also used as a media for promotion and information and establish communication with prospective customers and regular customers by using two CRM phases namely the acquisition phase and the retention phase. The results of this study are a CRM-based clinical information system with a reminder system feature.
\end{abstract}

Keywords: Clinic, CRM, Acquisition, Retention and Reminder System

\section{Pendahuluan}

Klinik umum dan bersalin Dokter Rini adalah salah satu perusahaan yang bergerak di bidang jasa pelayanan kesehatan. Berdasarkan wawancara dengan pihak klinik terdapat data jumlah pasien yang fluktuatif (Tabel 1). Pada tabel 1 terlihat bawasannya setiap bulan jumlah pasien yang berobat mengalami naik turun. Dikarenakan banyak presentase pasien yang tidak berobat kembali setelah dilakukan pemeriksaan. Hal ini disebabkan karena beberapa pasien merasa kecewa dengan layanan yang diberikan oleh klinik seperti kurang cekatan dalam 
penanganan pasien saat pasien mau berobat dan mengalami antrian yang panjang di loket pendaftaran, kurangnya informasi untuk memberitahukan kepada pasien pada saat adanya pemeriksaan kesehatan gratis seperti cek berat badan, gula darah, tekanan darah, kolestrol dan lainnya. Tidak ada wadah untuk menyampaikan keluhan pelayanan yang diberikan berupa kotak saran dan kritik. Serta belum ada sistem informasi di klinik dalam menyimpan data rekam medis.

Tabel 1. Jumlah pasien dalam enam bulan terakhir

\begin{tabular}{cccc}
\hline No & Bulan & Tahun & Jumlah Pasien \\
\hline $\mathbf{1}$ & Mei & 2018 & 476 orang \\
$\mathbf{2}$ & Juni & 2018 & 230 orang \\
$\mathbf{3}$ & Juli & 2018 & 440 orang \\
$\mathbf{4}$ & Agustus & 2018 & 443 orang \\
$\mathbf{5}$ & September & 2018 & 458 orang \\
$\mathbf{6}$ & November & 2018 & 395 orang
\end{tabular}

Jika permasalahan tersebut tidak segera di perbaiki, nantinya lebih banyak lagi keluhan dari pasien, seperti kecewa terhadap pelayanan yang berimbas kepada rasa kepuasan dan kepercayaan pasien untuk menggunakan layanan jasa kesehatan klinik tersebut. Sehingga membuat pasien pindah menggunakan pelayanan jasa kesehatan ke klinik lain yang mengakibatkan klinik kehilangan pelanggan [1]. Hal ini perlu diperhatikan dikarenakan akan perlu biaya yang lebih besar lagi dalam memperoleh pelanggan baru daripada mempertahankan pelanggan dan berpengaruh pada pendapatan keuntungan klinik ke depannya [2]. Sebagai pelaku bisnis di bidang pelayanan jasa kesehatan hal utama yang harus dilakukan klinik umum dan bersalin Dokter Rini adalah memperhatikan masalah pelayanan dan kepuasan pasien. Oleh sebab itu, untuk meningkatkan pelayanan, diperlukan strategi CRM yang memiliki 3 tipe yaitu strategis, operasional, dan analitis [3]-[5]. Disini peneliti memilih konsep CRM operasional yang berfokus pada otomatisasi cara perusahaan dalam berhubungan dengan pelanggan serta berbagai aplikasi software CRM yang memungkinkan fungsi pemasaran, dan penjualan dapat berjalan secara otomatis [3]. CRM merupakan strategi yang digunakan perusahaan untuk mengelola hubungan baik dengan pelanggan sehingga memberikan kontribusi dan keuntungan jangka panjang bagi perusahaan [6], [7].

CRM terdiri dari tiga fase yaitu akuisisi, retensi [8] dan development [2],[7]. Melalui CRM, perusahaan akan menguasai strategi acquiring, enhancing, dan retaining. Menurut [9] cara yang bisa digunakan dalam mendapatkan pelanggan baru pada fase akuisisi diklinik diantaranya dengan melakukan promosi jasa melalui website klinik dan media sosial seperti email, facebook, whatsapp dan lain-lainnya. Sedangkan fase retensi yaitu dalam mempertahankan pelangan yang menguntungkan. Menurut [10] klinik memberikan pelayanan berdasarkan kemauan pasien, nilai yang ditawarkan kepada pasien adalah hubungan proaktif dalam ketertarikan masing-masing pelanggan. Salah satu fitur yang bisa digunakan dalam memberikan informasi dalam mempertahankan pelanggan adalah fitur reminder system. Reminder sistem adalah pesan pengingat, reminder sistem dapat bermanfaat jika informasi konstektual digunakan untuk memberikan informasi pada waktu yang tepat dan tempat yang tepat [1]. Sehingga strategi agar pelanggan dapat kembali lagi dan pelanggan tersebut akan menceritakan kepada teman-temannya untuk berobat ke klinik umum dan bersalin Dokter Rini yang pelayanannya memuaskan [10]. Apabila implementasi konsep CRM berhasil pelanggan akan loyal terhadap klinik tersebut [9]. Oleh karena itu, penelitian in akan menghasilkan sistem informasi klinik berbasis CRM. 


\section{Metode Penelitian}

Adapun penelitian ini terdiri dari:

1. Wawancara

Yang dilakukan dengan pihak klinik sebagai teknik pengumpulan data yang langsung dalam bentuk tanya jawab untuk mengidentifikasi permasalahan yang ada di klinik.

2. Dokumentasi

Dilakukan dengan cara mengumpulkan dokumen-dokumen atau arsip-arsip yang berhubungan dengan topik peneliti yang akan diteliti.

3. Analisa, Perancangan dan Pembahasan Sistem

Setelah penulis mendapatkan permasalahan yang ada, penulis akan melakukan analisa terlebih dahulu. Setelah analisa selesai, penulis melakukan perancangan sistem. Maka dari itu perlu adanya analisa sistem yang sedang berjalan dan sistem yang akan diusulkan. Selanjutnya akan dilakukan perancangan sistem dengan menggunakan metode OOAD dengan tools UML. Langkah-langkahnya sebagai berikut:

a. Menganalisis masalah

Data yang diperlukan untuk membangun sistem ini dikumpulkan sebagai kebutuhan sistem. Setelah semua data yang dikumpulkan, penulis melakukan analisa untuk merumuskam permasalahan yang ada di klinik tersebut. Kemudian penulis menganalisa dan menggambarkan alur sistem yang lama dari data yang didapat sebelumnya. Selanjutnya data yang didapat dan analisa alur sistem yang lama, penulis kemudian menganalisa dan menggambarkan alur sistem yang baru yang nantinya dapat memecahkan masalah yang sering terjadi di klinik tersebut.

b. Proses yang terjadi dalam sistem

Fungsi sistem yang akan dibangun bersumber dari data yang diambil dari klinik tersebut untuk membangun sistem. Semua data yang diperlukan untuk membuat sistem digambarkan dalam bentuk rancangan analisis, adapun analisi yang digunakan pada penelitian ini adalah Usecase Diagram, Squence Diagram,Activity Diagram, dan Class Diagram,

c. Identifikasi objek

Pada penelitian ini yang menjadi objeknya adalah Klinik Umum dan Bersalin Dokter Rini.

d. Menentukan atribut (class)

Class adalah abstraksi dari entitas dunia nyata. Adapun atribut (class) dari sebuah sistem klinik yaitu akun admin, akun dokter, akun kepala klinik, akun customer service, akun pasien, customer service-promosi, customer service-reminder, pasien-rekam medis, pasien-komplain, pasien-konsultasi, pasien-voucher.

e. Mengidentifikasi operasi

Pada penelitian ini yang dapat diimplementasikan adalah Admin bisa melakukan (kelola akun, admin, customer service, dokter, kepala klinik, pasien), Customer Service bisa melakukan (input data pasien, kelola promosi, konsultasi, komplain, reminder, menggunakan voucher), Dokter bisa melakukan (kelola rekam medis), Kepala Klinik bisa (melihat laporan), Pasien bisa (melihat rekam medis, promosi, input konsultasi, komplain, cetak voucher).

Yang nantinya akan terdapat fitur reminder yang berfungsi untuk mengingatkan pasien melakukan kontrol ulang yang akan dikirimkan oleh CS ke pasien melalui e-mail dan whatsapp. Jika CS mengirim reminder melalui e-mail secara otomatis sistem akan mengirimnya ke semua e-mail pasien. Dan jika CS mengirim reminder melalui whatsapp, CS akan diarahkan ke whatsapp web, setelah itu CS memilih nomor pasien yang akan dikirim reminder untuk pasien yang harus kontrol ulang. 
4. Kesimpulan

Dengan adanya sistem CRM klinik yang nantinya akan mempermudah pihak klinik dengan pasien untuk berkomunikasi lebih mudah.

\section{Hasil dan Pembahasan}

\subsection{Analisa Sistem Yang Sedang Berjalan}

Sistem yang berjalan di klinik umum dan bersalin Dokter Rini yang pertama pendaftaran pasien, pasien mengisi form pendaftaran lalu pasien diberikan kartu berobat. Apabila pasien sudang terdaftar diklinik pasien dapat diperiksa oleh dokter. Tahap kedua, dokter memeriksa pasien. Pasien masuk ke ruangan dokter lalu dokter mulai melakukan pemeriksaan, lalu dokter mencatat diagnosa dan obat pasien, lalu bidan menyiapkan obat yang disuruh dokter. Tahap ketiga, rawat inap. Pasien melakukan rawat inap bagi yang membutuhkaan. Tahap keempat, pembayaran. Setelah selesai pemeriksaan dan pengobatan, pasien melakukan pembayaran secara cash dimana traksaksi dilakukan di klinik langsung.

Selain itu, klinik umum dan bersali Dokter Rini selama ini mendapatkan pelanggan baru dengan cara memasang spanduk di depan klinik dan dari mulut kemulut yang dilakukan oleh pasien, dan memberikan tarif yang terjangkau bagi masyarakat sekitar yang pada umumnya berpenghasilan menengah ke bawah.

Selanjutnya dalam mempertahankan pelanggan, klinik memberikan layanan ambulance gratis bagipelanggan yang sering melakukan pemeriksaan dan pengobatan. Terutama bagi pelanggan yang mempunyai penyakit berat seperti kecelakaan dan melahirkan untuk mengantarkan pasien ke rumah setelah dilakukannya pemeriksaan dan pengobatan.

\subsection{Analisa Sistem Usulan}

Sistem yang akan dirancang ini dibuat untuk menyimpan data pasien dan melakukan strategi untuk mendapatkan pelanggan baru dengan cara melakukan promosi melalui media sosial seperti facebook, whatsapp dan e-mail.

Selanjutnya, sistem di rancang untuk memudahkan pihak klinik berkomunikasi dengan pasiennya melalui facebook, whatsapp dan e-mail. Selain bisa komunikasi dengan pasien, sistem ini nantinya akan diberikan kotak komplain, konsultasi, melihat promosi dan mencetak voucher sehingga pasien dengan mudah menyampaikan keluhan-keluhan yang ada pada pasien. Selain itu, sistem ini akan dibuatkan sistem reminder untuk pasien yang akan melakukan kontrol ulang. Pasien yang melakukan pemeriksaan dan pengobatan rutin minimal 5 kali akan diberikan layanan ambulance gratis untuk mengantar pasien kerumah setelah selesai pemeriksaan dan pengobatan. Voucher reminder ini berlaku untuk pasien yang mempunyai penyakit berat seperti kecelakaan dan melahirkan.

\subsection{Tampilan Sistem}

Sistem yang diusulkan terdiri dari 5 aktor yaitu admin, customer service, dokter, kepala klinik, dan pasien. Admin dapat kelola akun admin, CS, dokter, kepala klinik, dan pasien. Customer service dapat input data pasien, kelola promosi,kelola konsultasi, kelola komplain, kelola reminder, dan menggunakan voucher. Dokter dapat kelola rekam medis. Kepala klinik dapat melihat laporan. Pasien dapat melihat rekam medis, promosi, konsultasi, komplain, dan cetak voucher. Admin dapat menambahkan data akun, melihat detail data akun, mengubah data akun, dan menonaktifkan data akun. Jika ingin menambah data akun, admin dapat mengklik tomboh tambah data akun, setelah itu admin memilih akun siapa yang akan di tambahkan yang ditunjukkan pada Gambar 1.

CS dapat memilih menu data pasien dan menambah data pasien, melihat detail data pasien, mengubah data pasien,. Jika ingin menambah data pasien, CS dapat mengklik tombol tambah data pasien, setelah itu CS akan menginputkan data pasien lalu klik tombol simpan untuk 
menyimpannya, setelah tersimpan CS bisa melihat data yang tersimpan di halaman data pasien. CS juga bisa melihat akun pasien setelah menekan tombol akun pasien lalu CS bisa melihat detail akun pasien, ubah akun data pasien seperti yang ditunjukkan pada Gambar 2.

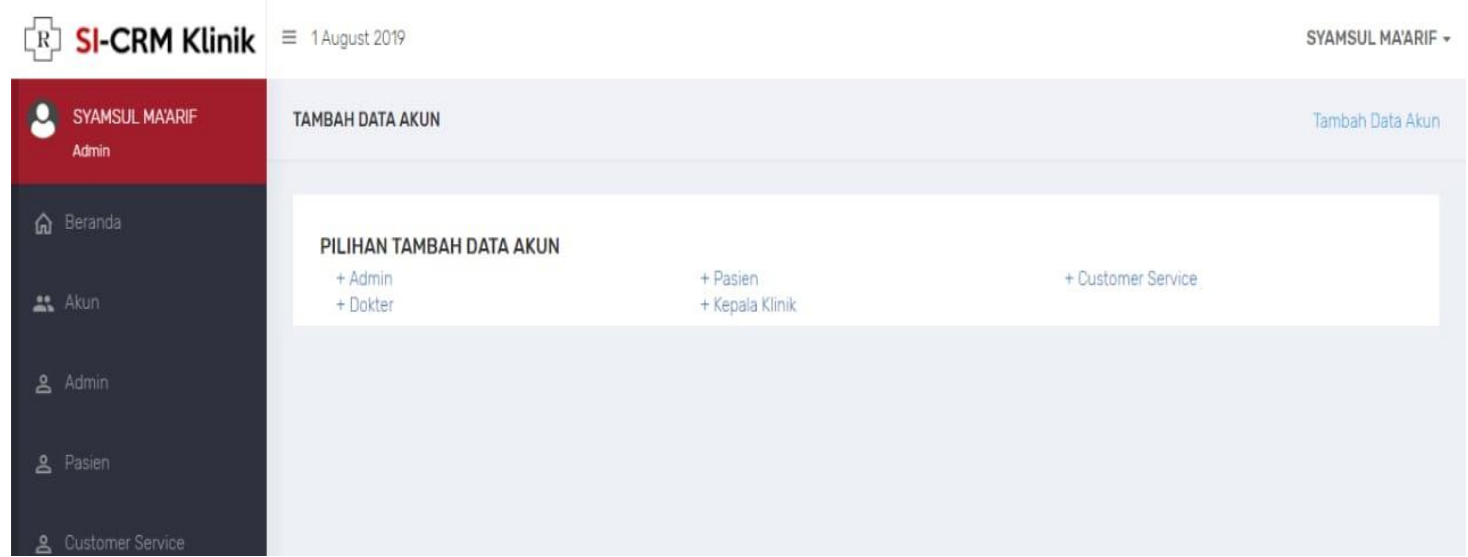

Gambar 1. Admin kelola akun
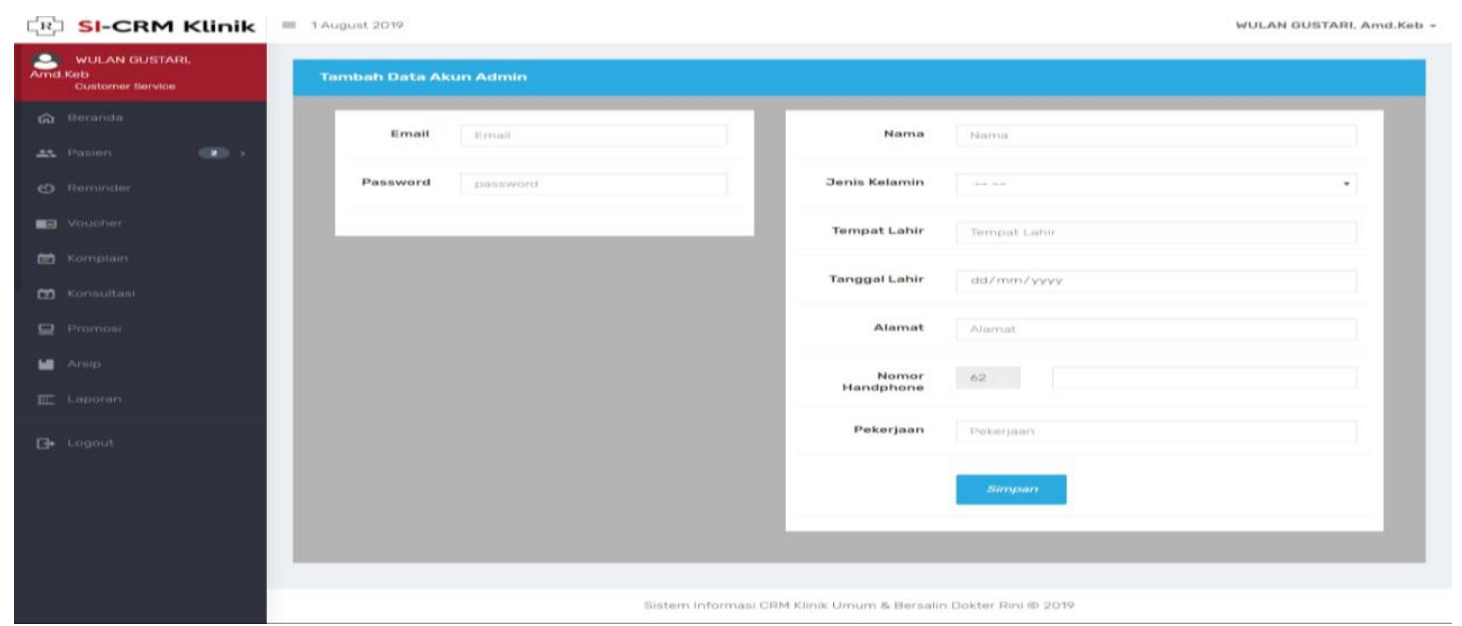

Gambar 2. CS Tambah data Pasien

Selain itu, CS dapat menambahkan promosi, melihat detail promosi, mengubah promosi, dan menghapus promosi dan mengirim promosi melalui facebook, e-mail dan whatsapp. Jika ingin menambah promosi, CS dapat mengklik tombol tambah promosi, setelah itu CS akan menginputkan promosi lalu klik tombol simpan untuk menyimpannya, setelah tersimpan CS bisa melihat data promosi yang tersimpan di halaman data promosi. Setelah itu CS menshare promosinya ke pasien dengan menekan tombol facebook, e-mail atau whatsapp. Jika CS mengirim promosinya melalui facebook sistem akan otomatis mengarahkan share ke facebook klinik tersebut, jika CS mengirim promosi melalui e-mail sistem otomatis akan langsung mengirim promosinya ke semua e-mail pasien, jika CS mengirim melalui whatsaap CS mengklik tombol whatsapp lalu CS akan diarahkan ke whatsapp web lalu CS mengirimnya ke nomor whatsapp pasien yang telah terdaftar di sistem seperti yang ditunjukkan pada Gambar 3.

Selanjutnya CS dapat menanggapi konsultasi dari pasien, jika CS ingin menanggapi konsultasi dari pasien, CS harus mengklik tombol lihat detail konsultasi, lalu CS menanggapi konsultasi dari pasien setelah itu CS mengirim dengan menekan tombol kirim seperti yang ditunjukkan pada Gambar 4. 


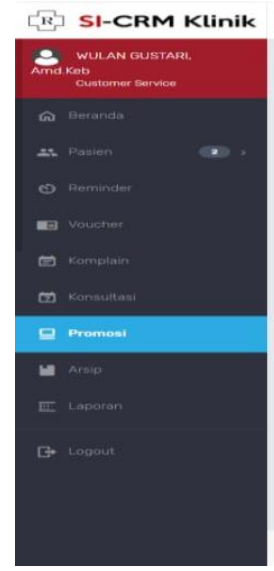

RI-CRM Klinik

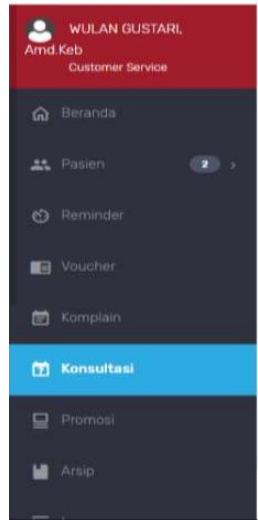

Selanjutnya CS juga dapat menanggapi komplain dari pasien, jika CS ingin menanggapi komplain dari pasien CS harus mengklik tombol lihat detail komplain, lalu CS menanggapi komplain dari pasien setelah itu cs mengirim dengan menekan tombol kirim seperti yang ditunjukkan pada Gambar 5.
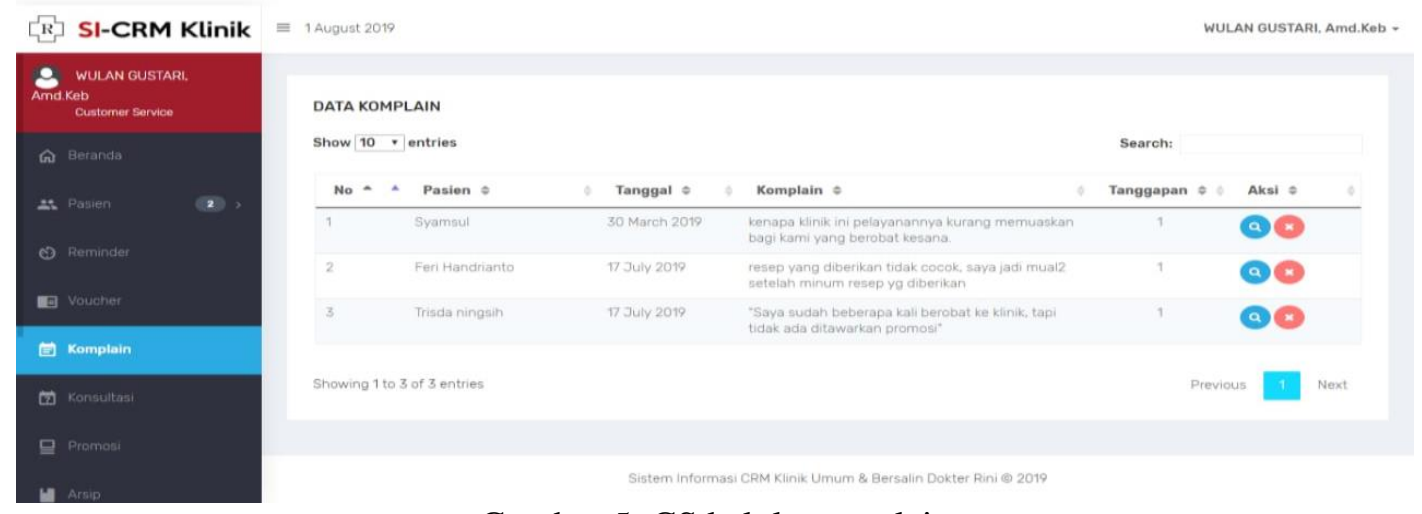

\section{Gambar 5. CS kelola complain}

CS juga dapat membuat reminder. Jika CS ingin membuat reminder pasien, CS dapat mengklik tombol reminder, setelah itu CS mengisi tanggal reminder dan mengisi konten reminder, lalu CS mengklik tombol buat reminder, setelah berhasil membuat reminder CS dapat 
mengklik tombol lihat data reminder, lalu CS mengirim reminder ke pasien yang telah di tentukan melalui e-mail dan whatsapp, jika mengirim melalui e-mail secara otomatis sistem akan mengirimnya ke semua pasien, apabila CS mengirim melalui whatsapp CS akan diarahkan ke whatsapp web setelah itu reminder akan dikirimkan ke nomor whatsapp pasien yang harus kontrol ulang ke klinik seperti yang ditunjukkan pada Gambar 6.
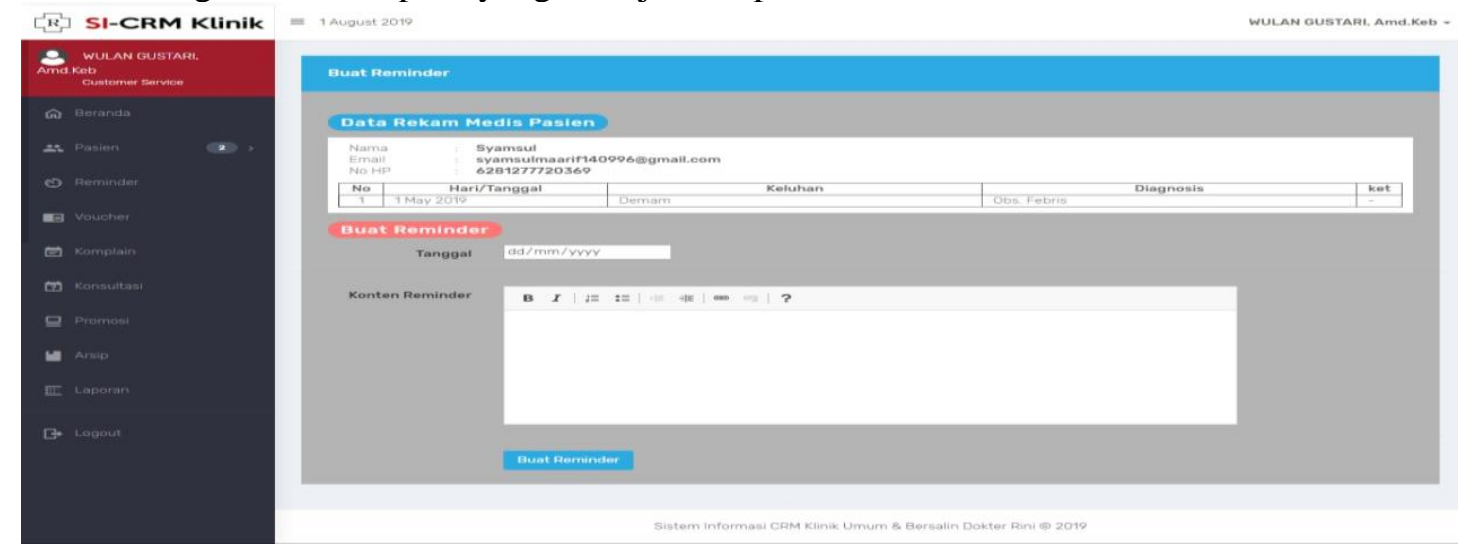

Gambar 6. CS kelola reminder

Pada halaman Pasien, pasien dapat melihat promosi. Pasien memilih menu promosi, setelah itu pasien mengklik tombol lihat detail promosi untuk melihat promosi yang ada di klinik tersebut seperti yang ditunjukkan pada Gambar 7.
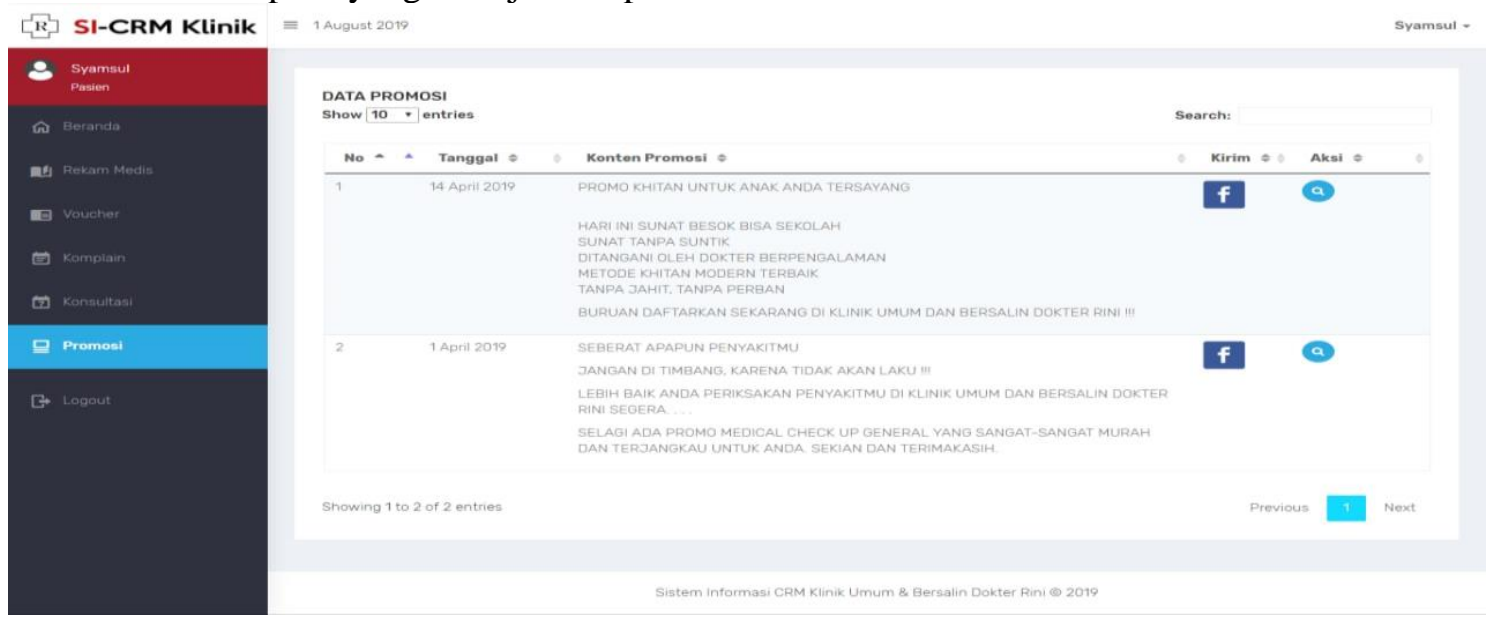

\section{Gambar 7. Pasien Lihat Promosi}

Selain itu, Pasien dapat mengisi konsultasi, jika pasien ingin membuat konsultasi pasien memilih menu konsultasi lalu pasien memngklik tombol tambah data konsultasi lalu pasien bisa mengisi konsultasinya yang nanti akan di kirim ke pihak klinik, setelah membuat konsultasi pasien bisa langsung mengirimnya, setelah mengirim pasien bisa melihat data konsultasinya di halaman data konsultasi seperti ditunjukkan pada Gambar 8.

Pasien dapat isi komplain, jika pasien ingin membuat komplain pasien memilih menu komplain lalu pasien mengklik tombol tambah data komplain lalu pasien bisa mengisi komplainya yang nanti akan di kirim ke pihak klinik, setelah membuat komplain pasien bisa langsung mengirimnya, setelah mengirim pasien bisa melihat data komplainnya di halaman data komplain. 
R SI-CRM Klinik $\equiv 1$ August 2019
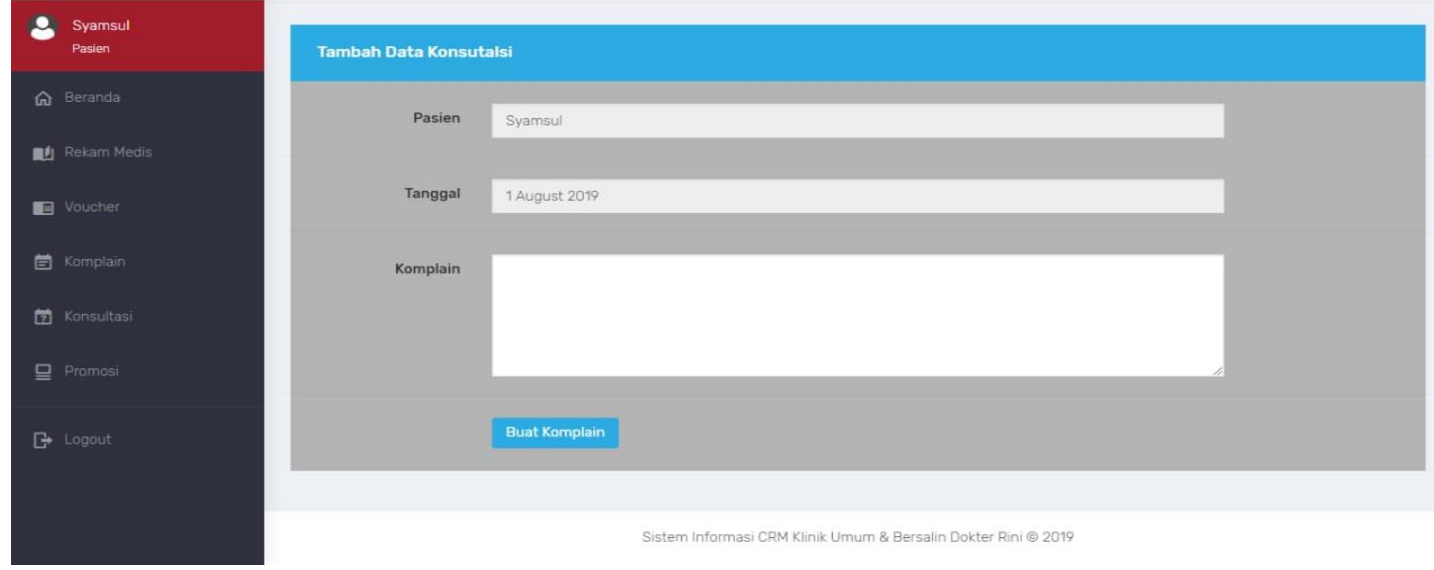

Gambar 8. Pasien isi konsultasi

SI-CRM Klinik
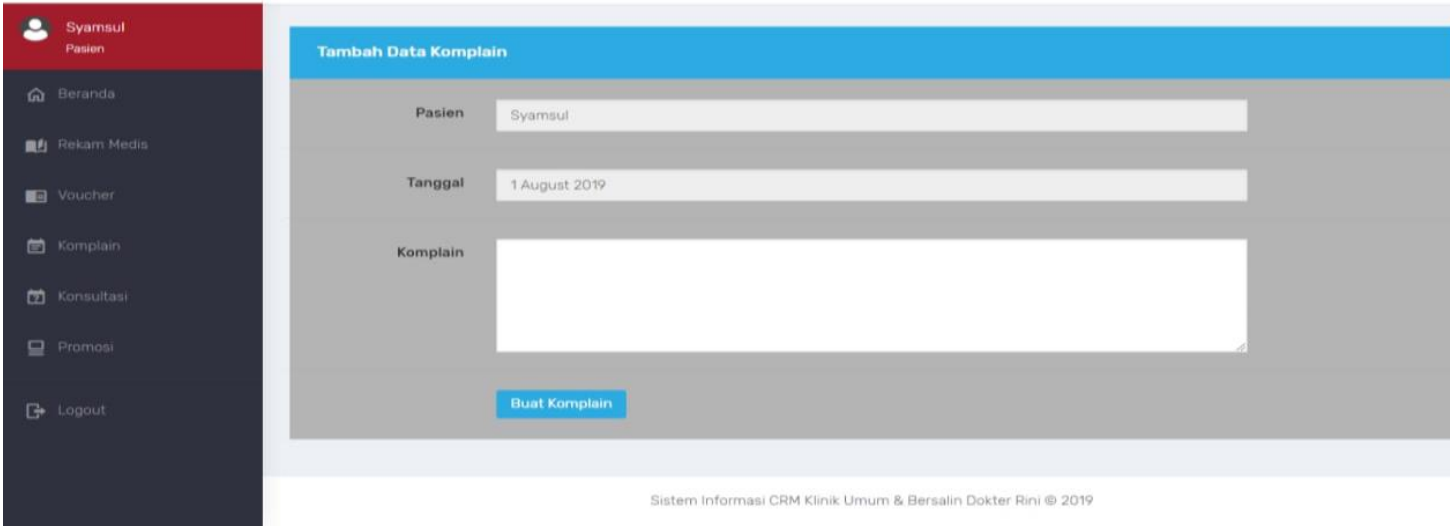

Gambar 9. Pasien input complain

Pasien juga dapat melihat voucher, jika pasien ingin lihat voucher pasien bisa melakukannya dengan cara mengklik tombol detail voucher seperti di tunjukkan pada Gambar 9.
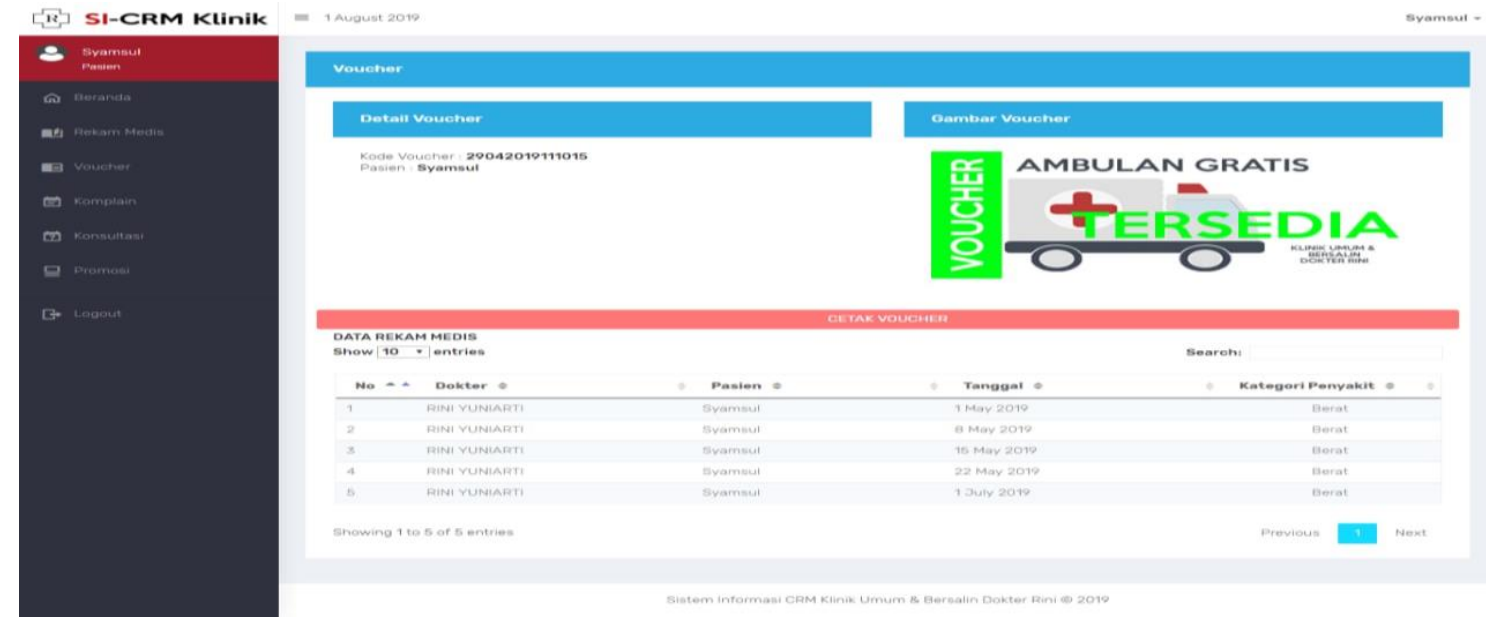

Gambar 10. Pasien lihat voucher 


\section{Kesimpulan}

Penelitian ini menghasilkan sistem informasi klinik berbasis CRM dengan tipe operasional. Sistem CRM ini bisa mempermudah klinik dalam mengendalikan semua proses bisnis yang berjalan seperti bagian administrasi, rekam medis, laporan untuk kepala klinik, dan pasien dengan terintegrasi dalam satu sistem.Dengan adanya sistem klinik berbasis CRM ini akan memudahkan klinik dalam mengelola data pasien dan memberikan kemudahan dalam menyampaikan informasi dan promosi kepada pasien serta menyediakan fitur reminder, konsultasi, komplain untuk menampung masukan dan keluhan dari pasien, dan promosi yang sedang berlangsung di klinik tersebut. Selain itu, Dengan adanya sistem klinik berbasis CRM ini dapat mempermudah pasien mendaftar untuk berobat secara online.

\section{Daftar Pustaka}

[1] T. Wijayanti, I. Azhari, A. Dahlan, J. Prof, S. H. Soepomo, and Y. Janturan, "Pengembangan Customer Relationship Management Berbasis Web pada Griya Muslim Flora," JUSI, vol. 1, no. 1, 2011.

[2] Nardiman, "Pengaruh Customer Relationship Management Dan Customer Value Terhadap Kepuasan Nasabah Dan Dampaknya Pada Loyalitas Nasabah Bank Bri Unit," $J$. EKOBISTEK, vol. 6, no. 2, pp. 251-262, 2017.

[3] E. Fuad and R. Ferdiana, Perancangan Fitur E-Commerce Berdasarkan Konsep Customer Relationship Management Untuk Meningkatkan Kualitas Pelayanan.

[4] F. Buttle and M. Stan, Customer Relationship Management, Third edit. ButterworthHeinemann, 2015.

[5] H. Tohidi and M. M. Jabbari, "The Necessity of Using CRM," Procedia Technol., vol. 1, pp. 514-516, 2012.

[6] S. Q. Moghaddam, N. Abdolvand, and S. R. Harandi, "A RFMV model and customer segmentation based on variety of products," J. Inf. Syst. Telecommun., vol. 5, no. 3, 2017.

[7] Y. B. Utomo, W. W. Winarno, and A. Amborowati, "Perancangan Customer Relationship Management Pada Klinik (Studi Kasus: Klinik Pratama Nusa Medika Meritjan)," Multitek Indones., vol. 10, no. 1, p. 57, 2016.

[8] E. C. Malthouse, M. Haenlein, B. Skiera, E. Wege, and M. Zhang, "Managing customer relationships in the social media era: Introducing the social CRM house," J. Interact. Mark., vol. 27, no. 4, pp. 270-280, 2013.

[9] R. A. Amal, "Hubungan Customer Relationship Management Terhadap Loyalitas Pasien Rawat Inap Di Rumah Sakit Ibnu Sina Kota Makassar Tahun 2017," universitas islam negeri alauddin makasar, 2017.

[10] R. Kalakota, M. Robinson, and R. Kalakota, E-business 2.0: roadmap for success. Addison-Wesley, 2001.

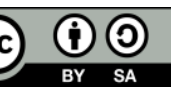

